have mounted daily. Action on Alcohol Abuse might address itself to this problem as its priority.

${ }^{1}$ Anonymous. Alcohol: clearing the decks for action. Br Med $\mathcal{F} 1982 ; 284$ 1360.

${ }^{2}$ Holtermann S, Burchell A. The costs of alcohol abuse. London: Department of Health and Social Security, 1981.

${ }^{3}$ Smith R. The politics of alcohol. Br Med F 1982;284:1392-5.

4 Special Committee of the Royal College of Psychiatrists. Alcohol and alcoholism. London: Tavistock Publications, 1979.

${ }^{5}$ World Health Organisation Expert Committee. Problems related to alcohol consumption. Geneva: WHO, 1979.

${ }^{6}$ Central Policy Review Staff. Alcohol policies in the United Kingdom. Stockholm: Sociologiska Universitet, 1982.

7 Department of Health and Social Security. National voluntary organisations and alcohol misuse. London: DHSS, 1982.

${ }^{8}$ Department of Health and Social Security. New voluntary organisation to deal with alcohol misuse. London: DHSS, 1982. (Press release 82/319.)

\section{Trimming fat or cutting bone?}

As the screw is turned down ever tighter on the finances of the NHS in the government's campaign for cost cutting and greater efficiency the medical and nursing staff in daily contact with patients are facing problems and choices of a totally unfamiliar kind. For many years clinicians committed to the NHS have glossed over its defects and defended it against critics; the time has now come for them to defend the service against its own masters by changing attitudes and publicising examples of patients suffering from delays and shortages. Leaders of the British Medical Association have already made strong representations to the Secretary of State for Social Services, ${ }^{1}$ and the association, through its representative machinery, is now asking doctors to report specific examples of the impact of cuts on the service they can offer their patients ( $p$ 848). The Royal College of Nursing is conducting a similar exercise ( $\mathrm{p} 848$ ).

The main cause for current concern is the Secretary of State's insistence on strict adherence by regions to his requirement for $1 \%$ cuts in manpower, with front line clinical staff included in these cuts. ${ }^{2}$ Regional chairmen have had no response to their complaints that the baseline chosen for the cuts-31 March 1983-has given a distorted picture since many posts were suspended during the restructuring of the NHS. ${ }^{3}$ Health authorities with big new hospitals on the brink of opening face particularly severe problems, since their planned increase in staffing has had to be converted into cuts. Arbitrary cuts imposed in the midst of a financial year are bound to have damaging effects, as Professor D W Vere argues at $\mathrm{p} 849$. While the government's intransigence on this issue shows how seriously it is taking its cost cutting exercise, the DHSS's inflexibility is seriously damaging morale among its regional and district administrators as well as among nurses and doctors. They had been told that one of the principles the most recent reorganisation of the NHS was the devolutio of decision making to the staff in touch with local opinionc4 Where is that principle now?

The DHSS is being equally intransigent in pushing throug its policies on privatisation (p 850). No doubt some hospitaf have had inefficient or poor quality services from theff laundries, cleaning staff, and kitchens; and in some cases $\frac{9}{4}$ private contractor might be able to offer a better deal. But whe NHS districts get together to plan a more efficient service ang the DHSS vetoes the plan-as has happened with the laundrg services in Calderdale ${ }^{5}$ the decision seems to reflect doctrin aire attitudes rather than the good of the service. Ministe should also be questioned about controls over the working conditions of staff employed by private contractors: saving should not be made at the cost of using sweated labour.

In all of the current dissension and protest we need remember that the decision to make cuts in the NHS budgetand notwithstanding ministerial protestations these are rea cuts $^{6}$-is a political one, made by a sovereign government dukw elected. But doctors have two clear obligations in these times of retrenchment and economies.

Firstly, doctors must be prepared to help identify exampl\& of cost cutting affecting the quality of care they are providing If economies result in lengthening waiting lists or in staff shortages jeopardising safety or the management of patients, the BMA wants to hear immediately. For its part, the Roya College of Nursing is asking regional and district nursing officers to make their assessment of the impact of the cuts services and is also "mobilising grassroots opinion."

Secondly, however, clinicians may have to accept that then can no longer claim total freedom to order investigations and prescribe treatments as they think best. Even in the affluegf United States doctors are being forced to conform to overall cost limits, and some form of clinical budgeting seems in evitable for the NHS. Doctors should be seen to be willing cooperate in efforts to improve their cost effectiveness.

The government claims that its programme of cuts can be achieved "painlessly." In the last few weeks many clinician have come to doubt this assertion-and Mrs Thatcher? famous pledge that "the NHS is safe with us." What is needed now is something more than opinions and responses that migt be categorised as emotional. If the medical and nursing pres fessions are to help defend the NHS their leaders need facts They can then tell the Secretary of State that having trimm the fat from the NHS he now risks cutting into its bone.

${ }^{1}$ Scrutator. The week. Br Med f 1983;287:437.

2 Department of Health and Social Security. Health services development cash limits and manpower targets for 1983-4. HC(83)16. London: DHS 1983.

${ }^{3}$ Anonymous. Reorganisation à la carte. [Editorial.] Br Med f $1982 ; 28 \frac{2}{2}$ 769-70.

1 Department of Health and Social Security. Patients first. London: HMSœ 1979.

${ }^{5}$ Healy P. Fowler demands action report by February on NHS contrag services. The Times 1983 Sep 9:2 (col 1-2).

${ }^{6}$ Anonymous. Government issues revised NHS cash limits. Br Med 7 198 287:700. 